\title{
Effect of Sand Faction Percentage in Soil Mixture towards Soil Support Power for Dam Construction
}

\author{
Lusmeilia Afriani $\mathbb{i D}^{1}$ and Ryzal Perdana ${ }^{2}$ \\ ${ }^{1}$ Department of Civil Engineering, Universitas Lampung, Bandar 35145, Indonesia \\ ${ }^{2}$ Department of Educational Science, Universitas Lampung, Bandar 35145, Indonesia
}

Correspondence should be addressed to Lusmeilia Afriani; afriani_1@eng.unila.ac.id

Received 10 June 2021; Revised 27 September 2021; Accepted 15 November 2021; Published 20 January 2022

Academic Editor: Junhui Zhang

Copyright (c) 2022 Lusmeilia Afriani and Ryzal Perdana. This is an open access article distributed under the Creative Commons Attribution License, which permits unrestricted use, distribution, and reproduction in any medium, provided the original work is properly cited.

\begin{abstract}
Knowledge of soil, which is an essential construction material, has great importance for dam construction. The level of density and carrying capacity of the soil is very important and should be taken into consideration in the planning and designing stages of civil construction, considering the soil functions as a means to withstand the load or structure built on it. Stabilization using sand soil material is one of the ways to meet the strength requirements of soil carrying capacity when there is no suitable soil material found in the nearby area. This paper aims to elucidate the physical properties of clay using a mixture of fine sand to reduce the risk of shrinkage when used for dam construction. Several analyses were carried out to find out the effect of the fine sand percentage in the clay mixture to decrease the swelling test value and permeability test of the soil carrying capacity for dam construction. The types of soil tested were silt clays taken from Tritisan subdistrict of East Lampung which were then stabilized using fine sand material from Central Lampung, Indonesia. This research was conducted using a mixture of sand, with percentages of $10 \%, 20 \%$, $30 \%$, and $40 \%$. Subgrade tests such as CBR and permeability tests were also undertaken to investigate other soil properties from each sample. The results indicate that a higher percentage of sand causes decreasing water content. Thus, the value of the carrying capacity of the soil is increasing. The findings can be used to facilitate the increasing use of clay mixtures with the percentage of fine sand in case suitable clay material cannot be found around dam construction sites. The implications with suggestions for future research are also discussed.
\end{abstract}

\section{Introduction}

Knowledge of soil, which is a basic construction material, has great importance for dam construction. It is one of the key factors of civilizations [1]. In the history of geology, there has been a close relationship between life and water from the perspective of the land and aquatic environment [2]. The soil is the critical element of life support systems because it delivers several ecosystem goods and services [3]. Soil properties diverse considerably under tillage type, intensity, different crops, fertilizer, and application rates [4]. It is well known that dam is one of irrigation infrastructure buildings with a type of weir structure that is affected by the fluctuating flow rates and water volumes of the river. Soil water evaporation curves both represent the laws of water content variation in the natural state [5]. Vital environmental protection and water management are constructed [6]. The occurrence of instability and the derailment of dam construction can exist when the strength of the structure is not in accordance with shear strength of the soil on the related site. It also gives nutrients on the sediments of the reservoir [7]. Besides the above things, however, many factors can cause failures and cracks in a dam body such as floods, earthquakes or explosions, human activities, and terrorist attacks against the dam [8]. Since dam is a part of geotechnical engineering in civil engineering, if a failure occurs which finally causes damage, it can be repaired by analyzing and designing the stability of the dam, including the factors that affect the stability of the dam [9]. It is closely related to the decrease of downstream taxa and uplifts the biomass [10]. 
In dam planning, it is generally accepted that one of the surveys that must be carried out is a material investigation [11]. One of the ways is by assessing the problems of dam constructions, which are built on clay in Indonesia, and clay soil is spread almost in all areas of Indonesia. Regarding the dam construction, the original compacted soil is usually used as a core. In contrast, clay soil material is needed because it is impermeable so that the dam can store water to serve a function as a reservoir. Therefore, it leads to upstream and downstream decreases considerably [12].

1.1. Soil Stabilization. Generally, soil stabilization refers to a particular way of improving soil properties through blending and mixing other materials. These improvements include the increasing dry unit weight, bearing capabilities, volume changes, the performance of in situ subsoils, sands, and other waste materials to strengthen road surfaces, and other geotechnical applications [13]. According to Bowles [14], if the soil found in a site is loose or very easily stressed or if it has an inappropriate consistency index, it has very high permeability or other undesirable traits that are not suitable for a development project. Soil stabilization must be carried out to resolve the above issues. In general, the method used to stabilize soil consists of one process or a combination of the following processes [14]:

(a) Mechanical, namely, compaction with various types of mechanical equipment such as a roller machine, dropping heavy objects, explosion, static pressure, texture, freezing, and heating.

(b) Additive, namely, the addition of gravel to cohesive soils, loam for grained soils, and chemical mixers such as cement, lime, volcanic ash/coal, lime and/or cement, asphalt cement, sodium, calcium chloride, and paper mill waste.

The methods or ways to improve soil properties are also very dependent on curing time; this is because, during the process of improving soil properties, chemical processes occur, which require time for chemicals present in the additive to react.

However, the carrying capacity of the clay is often criticized for its low capacity. Clay soil is generally a poor subgrade due to its low shear strength, so that the construction of a structure on this soil layer always faces several problems such as low bearing capacity and large shrinkage properties. Therefore, it is commonly suggested that optimal water content plays an important role in getting the maximum density level. In addition to impermeability needs, because a large number of soil volumes are needed, the source of the material is also one of the important things to take into account.

Thus, the properties of clay are still not completely understood. In other words, evidence on this question is presently inconclusive. Therefore, this paper aims to elucidate the physical properties of this type of soil using a mixture of fine sand to reduce the risk of shrinkage when used for dam construction.
1.2. Clay. Soil is a collection of minerals, organic matter, and relatively loose deposits, which are located on bedrock (Hardrock) [15]. It is a collection of solid parts that are not bound to one another (some of which may be organic material) and the cavities between the parts containing air and water [16]. According to Bowles [14], soil is a mixture of particles consisting of one type or all of the following types:

(a) Boulders are large pieces of rock, usually larger than 250 to $300 \mathrm{~mm}$ and ranging from of $150 \mathrm{~mm}$ to $250 \mathrm{~mm}$ in size; these rock fragments are called cobbles/pebbles.

(b) Gravel is a rock particle measuring from $5 \mathrm{~mm}$ to $150 \mathrm{~mm}$.

(c) Sand is a rock particle measuring from $0.074 \mathrm{~mm}$ to $5 \mathrm{~mm}$, which ranges from coarse with a size of $3 \mathrm{~mm}$ to $5 \mathrm{~mm}$ to fine material measuring $<1 \mathrm{~mm}$.

(d) Silt is rock particles measuring from $0.002 \mathrm{~mm}$ to $0.0074 \mathrm{~mm}$.

(e) Clays are mineral particles smaller than $0.005 \mathrm{~mm}$, which are the main source of cohesion in cohesive soils.

(f) Colloids are mineral particles that are stationary and smaller than $0.001 \mathrm{~mm}$.

Several soil physical and biological properties, for example, bulk density, aggregate stability, and soil microbial biomass are related to the content and turnover of soil organic matter (SOM). Organic matter and clay are intimately linked by a range of physical, chemical, and biological processes, playing a crucial role in the formation of soil aggregates, affecting stability at different scales [17].

Clay soils, which are very hard soil types in a dry state, are plastic at moderate water levels, whereas, in higher water conditions, the clay will be sticky (cohesive) and very soft [18]. It is the main concrete influencing dam safety operation [19]. The clay fraction of silica by $59 \%$ can result in crystallinity and stability of temperature [20]. It mostly contains palygorskite, kaolin, and sepiolite minerals [21]. They can be used to purify water and industrial substances [22]. The properties possessed by clay are as follows [15]:

(a) Fine-grain size, which is less than $0.002 \mathrm{~mm}$;

(b) Low permeability;

(c) High capillary water rise;

(d) Very cohesive;

(e) High levels of shrinkage;

(f) Slow process of consolidation.

Soft clay soil is soil containing clay minerals and has a high-water content, which causes low shear strength. Soft clay, also known as expansive clay, is a type of clay that is classified into types of soil which have a development value and a large shrinkage value, so that it can cause damage to the structures built on it. Due to the amount of activity value (A) of clay soil, the size of clay activity value is influenced by the soil plasticity index value (PI). Potential development of a type of soil is based on its plasticity index value (PI). Clay 
soils that can be categorized into expansive clay soils are those having very high development potential limits with the plasticity index value (PI) of $>35 \%$ [20].

Thus, the properties of clay are still not completely understood. In other words, evidence on this question is presently inconclusive. Sand is a naturally occurring granular material. Because of its high load bearing capacity in confined condition, sand could be used as a filler material. It could be used in varying proportions as admixture to cohesive soils altering the properties of plasticity, compaction, and strength of the mixtures. Therefore, this paper aims to elucidate the physical properties of this type of soil using a mixture of fine sand to reduce the risk of shrinkage when used for dam construction.

\section{Materials and Methods}

2.1. Research Sites. This study focused on soil samples taken from Pringsewu and Margatiga subdistricts in East Lampung Regency, Indonesia, where dam construction was taking place.

2.2. Soil Compaction. Compaction is an attempt to increase the density of the soil by releasing air to the porous soil, which is usually done using mechanical energy. In the field, compaction effort is related to the amount of runoff from a roller machine or something else that has the same principle for a certain volume of soil. In general, soil compaction, which is carried out in the laboratory, consists of two types, namely, the AASHTO T99 Proctor Standard (ASTM D689) and Modified Proctor, to obtain a greater California Bearing Ratio (CBR) value. Undertaking a soil compaction test will make a connection between water content and volume weight. According to Bowles [14], the benefits derived from compaction of soil include: the following

(a) Reduced subsidence, that is, vertical movement within the soil mass itself due to reduced number of pores;

(b) Increasing soil strength;

(c) Decreasing volume due to reduced water content during drying.

2.3. California Bearing Ratio (CBR). California Bearing Ratio (CBR), which was first invented between 1927 and 1930 in California by O.J. Porter, is an empirical method for measuring soil density values. This method combines an experiment of loading in the laboratory or in the field with an empirical plan to determine the thickness of the pavement layer. A CBR test must first be carried out to get the CBR value. This test, a comparison between test loads with standard load, expressed as a percent, was developed around the 1930s in the laboratory of the Materials Research Department of the California Division of Highway, USA.

2.4. Dam Construction. According to Indonesian Government Regulation Number 37 Article 1 of 2010 about Dams, a dam is a building made of earth, rock, concrete, and/or stone pairs to hold and store water. It is also built to hold and accommodate mine waste (tailings) or collect mud to form a reservoir. A dam serves to function as a water catcher and saves the water during the rainy season when the river water flows in large quantities and exceeds the needs for use, irrigation, drinking water, industry, or others. In the Guidelines and General Criteria of Dam [11], the types of dam based on its function can be divided into the following:
(a) water reservoir dam;
(b) diversion dam;
(c) flood control dam;
(d) Multipurpose dam.

Based on the material, dams are classified into the following:
(a) concrete gravity dam;
(b) concrete dam with buttresses;
(c) arch dam;
(d) landfill dam;
(e) rockfill dams.

During the planning and designing stage, site selection and type of dam must be considered very carefully. The factors that should be taken into account when selecting the type of dam are as follows:

(a) The purpose of the dam building;

(b) Protection against overflow;

(c) Limitations on building expenses;

(d) Problems encountered in flow diversion during construction;

(e) Easy access to dam locations;

(f) Availability of labor and equipment;

(g) Physical factors of dam location;

(h) Dam safety.

In other words, it is important to conduct surveys and investigations to determine the type and design of a dam that will be built. This is to avoid construction failure that can cause disaster. During the construction stage, several dam safety issues could be encountered, particularly the risk of piping failure of the existing dam due to foundation excavation for the dam construction. The variability in geology site, foundation conditions, construction materials, and site conditions of the project added to the risk of the project [23].

The material investigation must be carried out to assess and determine the physical and mechanical properties of the dam material and the availability of material reserves. The backfill dam material test is carried out to investigate the physical properties, dynamic properties, and rock tests. The test is carried out on waterproof material, semiwaterproof material, and watergraduated material. The need for this type of test is listed in the Guidelines, General Criteria, and Design of [11] for design and construction of reservoirs. 
2.5. Sampling. The soil was sampled using a 4-inch tube with a length of $50 \mathrm{~cm}$ from three different locations. The tube was inserted into the ground at a depth of $50 \mathrm{~cm}$. Plastic covers were used as soon as the earth tube was removed to maintain its original moisture content. Soil samples were then taken to the laboratory for basic tests to obtain the basic properties that were later used as primary data, as shown in Figures 1 and 2.

2.6. Equipment. The equipment used in this study was tools for filter analysis test (to assess for information and apply logic to get patterns of the study), specific gravity test (to see the concentration of all present particles), water content test (divide the mass of water by dry soil mass multiplied by 100), consistency limit test (control and identify small quantities of impurity in the substance), modified Proctor test (compaction of soil by its types and properties according to the change of moisture content, dry density, and its relation), and CBR test which belongs to a penetration test applied to evaluate road and pavement's strength. Its results are used by the curve to find out the layers' thickness of pavement and its component for flexible design (a cylindrical steel mold and by using a cylindrical steel plunger to force it with nominal diameter of $50 \mathrm{~mm}$ at a controlled rate) and other equipment to test the thickness of layers (Atterberg limits, calcium carbonate content, and expansion and swell of soil) in the Soil Mechanical Laboratory, Department of Civil Engineering, University of Lampung, which has been suitable with the standardization of the American Society for Testing Materials (ASTM) D698 or AASHTO T99 and modified ASTM D1557 and AASHTO T180. To test the soil mixture, three tests were applied: permeability test (to know the ability of porous media), compaction test (to identify soil compaction properties), and pinhole test (to find out clay soils dispersity).

2.7. Method of Mixing Soil and Sand Samples. This research was conducted using sand as a mixture with variations in the percentages of sand of $10 \%, 20 \%, 30 \%$, and $40 \%$ [24].

\section{Data Processing and Analysis}

Basic soil tests such as water content, soil content, Atterberg limit, compaction, permeability, swelling, and triaxial were undertaken at the Soil Mechanical Laboratory of the Department of Civil Engineering, University of Lampung, following ASTM D698 or AASHTO T99 and modified ASTM D1557 and AASHTO T180. The ASTM Standard is used to develop and publish voluntary consensus of technical standard for various products, materials, services, and system [24].

3.1. Permeability Test. Permeability illustrates the ability of porous media, which allows fluid to flow. The flow of water through granular soil or rock mass is a common concern in geotechnical engineering. It is defined as the movement of fluid by porous media linked with materials' durability [25]. The samples were tested using a falling head procedure with the coefficient of permeability $(k)$ as the output. This experiment is a common laboratory testing method used to determine the permeability of fine-grained soils with intermediate and low permeability such as silts and clays. The falling head permeability test involves the flow of water through a relatively short soil sample connected to a standpipe, which provides the water head, which also allows measuring the volume of water passing through the sample. Firstly, saturated and standpipes soil samples were filled with deaired water to a given level. The test was then started by allowing water to flow through the soil sample until it reached a given lower limit. The time required for the water to drop from the upper to the lower level was recorded. The steps were repeated for a couple of times in which the recorded times should be within an allowable variation of about $10 \%$; otherwise, the test was considered as a failure. The method was used to look at the coefficient of permeability.

3.2. Compaction Test. A standard Proctor compaction test was undertaken to find out the soil compaction properties, where it has the optimal water content at which soil can reach its maximum dry density. It recognized and established guidelines to provide criteria for performance and methodologies test for compaction [24]. The output of this test would then be used to make CBR test samples. Samples were soaked for four days to see the changes of volume, and a dial gauge was installed to measure the volume changes. Shrinkage value could be read from the swelling value measured by the dial gauge.

3.3. Pinhole Test. A pinhole test was conducted to investigate the dispersity of clay soils. The piping failures of a number of homogeneous Earth dams, erosion along channel or canal banks, and rainfall erosion of earthen structures have been attributed to the colloidal erosion along cracks or other flow channels formed in masses of dispersive clay from Tritisan subdistrict of East Lampung, Indonesia. The test was undertaken by flowing water horizontally with $50 \mathrm{~mm}$ of air pressure on soil samples, and a hole was made with $1 \mathrm{~mm}$ of diameter. It was firstly proposed as a tool to evaluate susceptibility of compacted fine-grained soils to pipping by using a flow of passing water [26]. Also, the pinhole test, Emerson's crumb test, was conducted. Emerson's crumb test provided the potential of clay soils erodibility by using ASTM D4647/ D4647M-13 (2020) as the Standard Test Method for Identification and Classification of Dispersive Clay Soils by the Pinhole Test. The test consisted of a cubical specimen of about $15 \mathrm{~mm}$ on a side or selecting an airdried soil crumb of about equal volume. The specimen was then placed in distilled water. As the soil began to hydrate, the tendency for colloidal-sized particles to deflocculate and suspend was observed. 


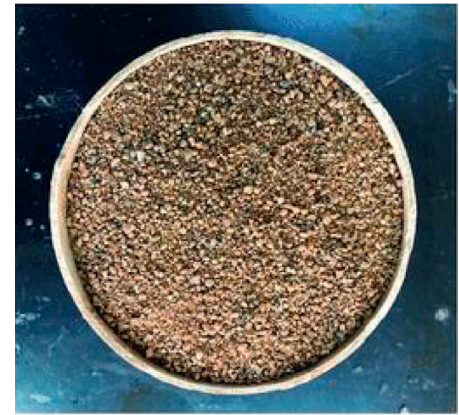

(a)

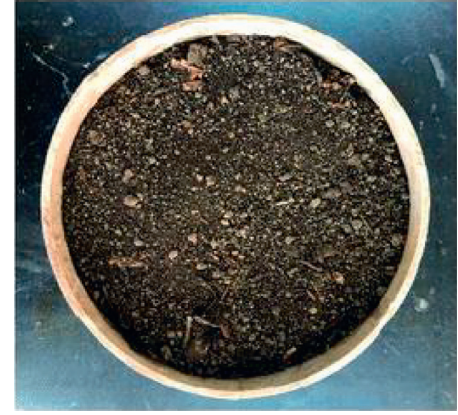

(b)

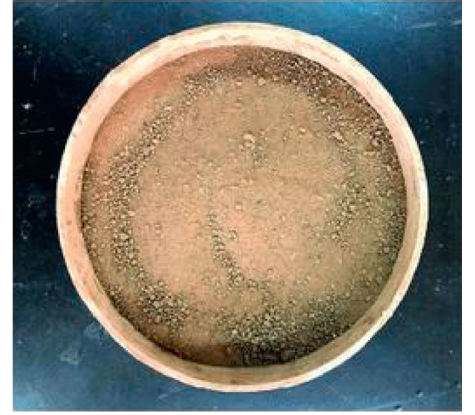

(c)

Figure 1: A soil sample from 3 different locations.

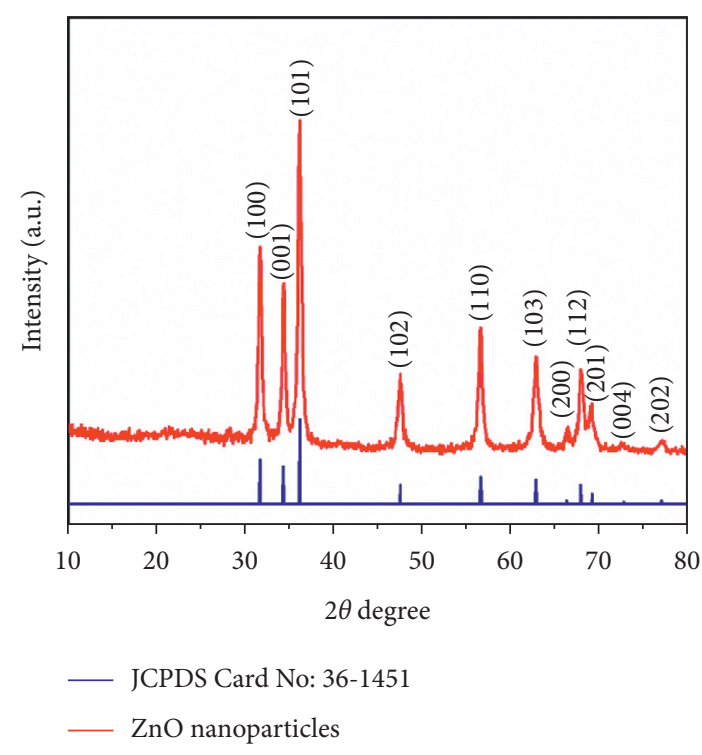

FIGURE 2: Soil XRD findings.

\section{Results and Discussion}

Preliminary research, including soil properties testing, soil physical properties, and compaction testing, was conducted. The data obtained in this study came from a series of filter analysis tests carried out in the laboratory and then presented systematically and clearly so that it could be analyzed. The data obtained were specific gravity, liquid limit and plastic limit, and MDD, OMC, UCS, and CBR values without curing and UCS and curing CBR. From the results of the preliminary survey, dam body materials could be obtained from the surrounding area in terms of volume. The physical properties themselves did not meet the technical requirements for a dam Biochemical Oxygen Demand (BOD) although the soil material from surrounding area could be used as the mixture of fine sand. The analysis results of soil samples taken from the study sites conducted in the laboratory can be seen in Table 1 .

In expansive soil, such as clay, it is acceptable to state that the volume of soil changes related to the change of water content and its pressure that occurred in the soil. These volume changes can lead to either swelling or shrinkage. The pressure, which the expansive soil exerts if it is not allowed to swell or if the volume change of the soil is drained, is known as swelling pressure of soil. The swelling pressure is affected by several factors such as (a) the type of clay in the soil and the nature of clay minerals, (b) moisture content and dry density, (c) fluid properties, (d) soil stress and pressure limits, and (e) drying and wetting cycle. After the CBR and shear strength (qu) values were obtained for each variation of clay and sand from the study sites, the CBR and qu values were analyzed in relation to influential factors such as soil mix composition, soil density, and also water content. The facts that the CBR value and the shear strength value (qu) are related to the soil mixture and that an increase in shear strength and CBR occurs significantly after mixing sand gradation into the clay need to be seen [27]. The following are the results of the analysis of soil properties, as shown in Table 2.

Compressibility is an important parameter in a dam construction due to its instability that might cause bigger problems such as collapsing. The experiments showed that the coefficient of consolidation ( $\mathrm{Cv}$ ) obtained was in the range of $0.201 \mathrm{~cm}^{2} / \mathrm{sec}$ to $0.942 \mathrm{~cm}^{2} / \mathrm{sec}$ with $29.44 \%$ and $34 \%$ of sand that passed sieves no. 200 and no.4, respectively. Meanwhile, the values of the compression index (Cc) obtained were between 0.48 and 0.29 , as seen in Table 1 . The most significant consolidation that occurred when the ratio of the fine grain was much higher than clay is shown by the high value of $\mathrm{Cv}$. It presents essential environmental protection and water management [6]. However, the compressibility process might happen during and after the construction process as newly added loads. At this rate, it might become very extensive and excessive pore water pressure.

4.1. Relationship between Water Content and Frictional Angle, Cohesion, and Density. The presence of water content creates pore water pressure that affects the effective stress of soil. In addition to water content, soil cohesion, shear strength, and compaction energy affect the bearing capacity of the soil. The relationship between water content, frictional angels, cohesion, and density is shown in Figure 3.

Figure 3 shows the relationship between water content and frictional angle. The result shows that the frictional angle 
TABLE 1: Soil sample testing result.

\begin{tabular}{|c|c|c|c|c|c|c|c|c|c|c|}
\hline \multirow[b]{2}{*}{ No. } & \multirow[b]{2}{*}{ Sample code } & \multirow[b]{2}{*}{ Depth (m) } & \multicolumn{4}{|c|}{ Density } & \multicolumn{4}{|c|}{ Triaxial UU } \\
\hline & & & $\begin{array}{c}\mathrm{MDD} \\
\left(\mathrm{Kn} / \mathrm{m}^{3}\right)\end{array}$ & $\begin{array}{c}\mathrm{OMC} \\
(\%)\end{array}$ & $\begin{array}{c}\mathrm{MBD} \\
\left(\mathrm{Kn} / \mathrm{m}^{3}\right)\end{array}$ & $\begin{array}{c}\text { Joule } \\
\text { (degree) }\end{array}$ & $\begin{array}{c}\mathrm{C} \\
(\mathrm{kPa})\end{array}$ & $\begin{array}{l}\mathrm{W} \\
\%\end{array}$ & $\begin{array}{l}\text { Density } \\
\left(\mathrm{Kn} / \mathrm{m}^{3}\right)\end{array}$ & Gs \\
\hline 1 & A. 3 & 01.40 & 1.190 & 37.16 & 1.632 & 13.50 & 1.61 & 31.94 & 1.62 & 2.57 \\
\hline 2 & AL.6 & $01.00-01.40$ & 1.190 & 47.28 & 1.753 & 16.02 & 1.23 & 44.76 & 1.58 & 2.56 \\
\hline 3 & AL.7 & 01.40 & 1.160 & 38.09 & 1.602 & 20.92 & 0.37 & 37.99 & 1.59 & 2.59 \\
\hline 4 & AL.7 & 02.30 & 1.160 & 39.58 & 1.619 & 16.20 & 1.29 & 37.33 & 1.68 & 2.57 \\
\hline 5 & AL. 8 & 01.50 & 1.280 & 39.85 & 1.790 & 16.14 & 1.32 & 36.37 & 1.69 & 2.58 \\
\hline 6 & AL. 8 & 02.60 & 1.250 & 37.27 & 1.716 & 10.13 & 2.24 & 38.08 & 1.74 & 2.60 \\
\hline 7 & AL.9 & 01.30 & 1.200 & 39.46 & 1.674 & 10.07 & 1.45 & 39.81 & 1.68 & 2.65 \\
\hline 8 & AL.9 & 02.60 & 1.250 & 47.52 & 1.844 & 19.02 & 1.11 & 39.21 & 1.64 & 2.55 \\
\hline 9 & TP.1 & 02.00 & 1.310 & 38.39 & 1.813 & 12.21 & 1.01 & 35.22 & 1.67 & 2.51 \\
\hline 10 & TP.1-1 & $01.00-01.40$ & 1.330 & 35.35 & 1.800 & 17.34 & 0.37 & 35.98 & 1.70 & 2.64 \\
\hline 11 & TP.2-1 & $01.00-01.40$ & 1.250 & 35.47 & 1.693 & 15.77 & 0.82 & 34.52 & 1.71 & 2.64 \\
\hline 12 & TP.4 & $01.00-01.40$ & 1.390 & 32.20 & 1.838 & 6.11 & 1.07 & 32.89 & 1.73 & 2.44 \\
\hline 13 & TP.4-2 & 02.10 & 1.320 & 35.78 & 1.792 & 17.87 & 0.30 & 32.24 & 1.70 & 2.54 \\
\hline 14 & TP. 8 & $01.75-02.15$ & 1.350 & 43.88 & 1.942 & 4.26 & 0.56 & 48.36 & 1.71 & 2.55 \\
\hline 15 & TP.9 & $01.30-01.70$ & 1.130 & 44.44 & 1.632 & 14.64 & 0.82 & 49.24 & 1.65 & 2.44 \\
\hline 16 & TP.11 & $02.60-03.00$ & 1.420 & 32.20 & 1.877 & 13.80 & 0.94 & 43.44 & 1.73 & 2.42 \\
\hline 17 & TP.11-1 & $01.60-02.00$ & 1.070 & 41.17 & 1.510 & 25.40 & 0.22 & 40.95 & 1.60 & 2.48 \\
\hline
\end{tabular}

TABLE 2: Indexes properties of soil.

\begin{tabular}{|c|c|c|c|c|c|c|c|c|c|c|c|c|c|}
\hline $\begin{array}{l}\text { Sample } \\
\text { code }\end{array}$ & $\begin{array}{c}\% \text { integers no. } \\
200 \\
\end{array}$ & $\begin{array}{c}\% \text { integers no. } \\
4 \\
\end{array}$ & $\mathrm{~K}(\mathrm{~cm} / \mathrm{s})$ & $\begin{array}{l}\mathrm{w} \\
\% \\
\end{array}$ & $\begin{array}{c}C^{\prime} \\
(\mathrm{kPa})\end{array}$ & $\begin{array}{c}\phi \\
\left({ }^{\circ}\right) \\
\end{array}$ & $\begin{array}{c}\gamma \\
\left(\mathrm{Gr} / \mathrm{cm}^{3}\right) \\
\end{array}$ & $\mathrm{Sr}$ & $\begin{array}{c}\mathrm{Cv} \\
\left(\mathrm{cm}^{2} / \mathrm{s}\right)\end{array}$ & $\mathrm{Cc}$ & $\begin{array}{c}\mathrm{LL} \\
\% \\
\end{array}$ & $\begin{array}{c}\mathrm{PL} \\
\% \\
\end{array}$ & $\begin{array}{l}\text { PI } \\
\% \\
\end{array}$ \\
\hline A. 3 & 13.66 & 58.72 & $2.80 . E-03$ & 31.94 & 0.68 & 14.79 & 1.19 & 76.15 & 0.34 & 0.47 & 53.45 & 41.21 & 12.24 \\
\hline AL. 6 & 6.25 & 77.21 & 8.13.E- 03 & 44.76 & 0.41 & 20.20 & 1.19 & 102.93 & 0.38 & 0.12 & 68.17 & 55.45 & 12.71 \\
\hline AL.7 & 19.71 & 66.31 & $3.11 . E-04$ & 37.99 & 0.30 & 30.26 & 1.16 & 79.82 & 0.26 & 0.14 & 58.88 & 48.95 & 9.93 \\
\hline AL.7 & 11.56 & 70.56 & $1.98 . E-02$ & 37.33 & 0.35 & 30.05 & 1.16 & 81.13 & 0.30 & 0.05 & 60.86 & 43.36 & 17.50 \\
\hline AL.8 & 9.37 & 68.56 & 1.46.E- 02 & 36.37 & 0.28 & 29.32 & 1.28 & 89.43 & 0.31 & 0.13 & 61.08 & 46.72 & 14.36 \\
\hline AL. 8 & 17.27 & 63.82 & 9.37.E- 04 & 38.08 & 0.34 & 30.76 & 1.25 & 98.23 & 0.48 & 0.24 & 46.36 & 31.07 & 15.29 \\
\hline AL.9 & 19.70 & 67.05 & $1.11 . E-03$ & 39.81 & 0.32 & 29.54 & 1.20 & 104.40 & 0.20 & 0.05 & 72.85 & 58.00 & 14.85 \\
\hline AL.9 & 14.21 & 70.05 & $1.40 . E-03$ & 39.21 & 0.31 & 33.69 & 1.25 & 89.28 & 0.48 & 0.36 & 64.75 & 47.52 & 17.23 \\
\hline TP.1 & 19.45 & 54.68 & 3.29.E- 03 & 35.22 & 0.31 & 27.62 & 1.31 & 101.37 & 0.94 & 0.07 & 62.95 & 51.37 & 11.58 \\
\hline TP.1-1 & 8.12 & 77.18 & $6.88 . E-03$ & 35.98 & 0.25 & 32.01 & 1.33 & 95.52 & 0.43 & 0.11 & 56.45 & 42.90 & 13.54 \\
\hline TP.2-1 & 20.04 & 65.01 & 4.26.E- 04 & 34.52 & 0.22 & 22.62 & 1.25 & 83.04 & 0.35 & 0.08 & 51.95 & 41.79 & 10.16 \\
\hline TP.4 & 15.02 & 73.74 & $2.14 . E-03$ & 32.89 & 0.31 & 23.67 & 1.39 & 104.73 & 0.35 & 0.11 & 44.56 & 25.78 & 18.78 \\
\hline TP.4-2 & 16.78 & 50.84 & 1.49.E- 03 & 32.24 & 0.33 & 25.56 & 1.32 & 93.39 & 0.46 & 0.14 & 58.31 & 35.17 & 23.14 \\
\hline ТР.8 & 6.90 & 71.89 & 8.84.E- 03 & 48.36 & 0.70 & 16.08 & 1.35 & 129.74 & 0.37 & 0.10 & 71.36 & 53.74 & 17.62 \\
\hline TP.9 & 14.10 & 71.14 & 1.89.E- 03 & 39.24 & 0.35 & 28.74 & 1.13 & 97.43 & 0.16 & 0.07 & 64.64 & 51.37 & 13.27 \\
\hline TP.11 & 14.33 & 48.95 & $2.51 . E-03$ & 43.44 & 0.37 & 21.06 & 1.42 & 123.80 & 0.36 & 0.29 & 73.49 & 51.19 & 22.30 \\
\hline TP.11-1 & 19.85 & 66.24 & 2.46.E- 04 & 40.95 & 0.35 & 27.99 & 1.07 & 77.21 & 0.24 & 0.10 & 64.91 & 52.44 & 12.47 \\
\hline
\end{tabular}

value increased as the water content increased until it reached $40 \%$ of water content. The frictional angle value was obtained from the Triaxial CU test. Figure 3 illustrates the relationship between soil cohesion and water content. The result shows that the cohesion decreased rapidly with increasing water content and did not change much afterward.

Figure 4 gives information about the relationship between water content and soil density. The result shows that the maximum density was obtained with $32 \%$ of optimum water content, and it kept decreasing as water content increased. The frictional angle is closely related to the cohesion of soil. The frictional angle and cohesion of soil are increased to a maximum value along with the addition of water content. The highest cohesion value was obtained when water was added in its optimum volume, which was between $37 \%$ and $40 \%$, as seen in Figures 3 and 4 . There were 17 experiments carried out in total. However, 2 experiments showed dissimilar results. At water content between $35 \%$ and $40 \%$, the soil density ranged from 1.15 $\mathrm{gr} / \mathrm{m}^{3}$ to $1.35 \mathrm{gr} / \mathrm{m}^{3}$ and decreased with further water addition, as seen in Figure 5. It is in line with the considerable upstream and downstream decreases between content and soil density [12].

4.2. The Relationship between Soil Mixture Variations and Permeability. It was found from the experiments that the clay and sand ratio affected the coefficient of permeability. The result showed that the coefficient of permeability 


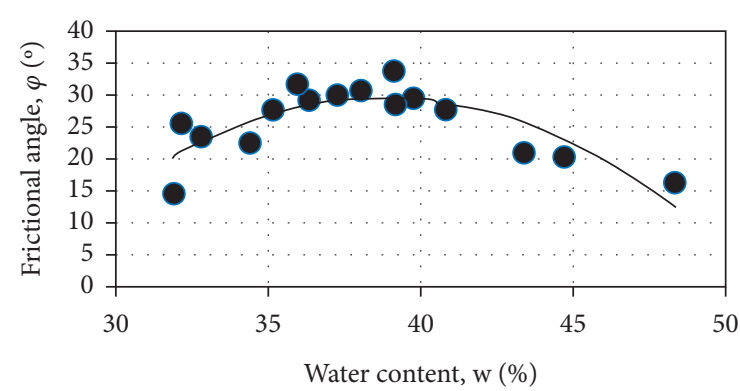

Figure 3: Highest cohesion value.

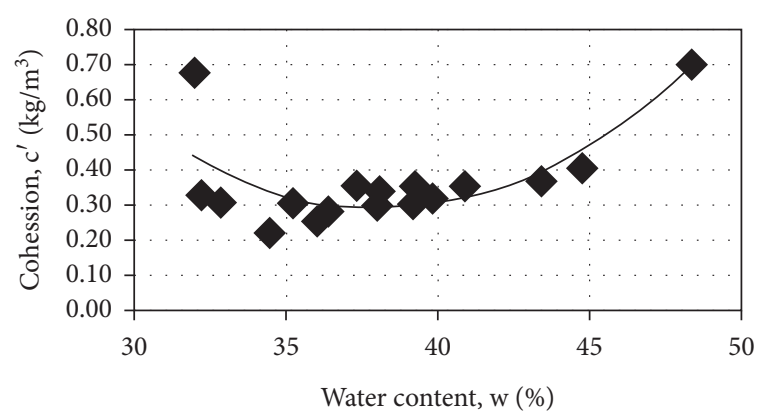

FIgURE 4: Highest cohesion value-added water.

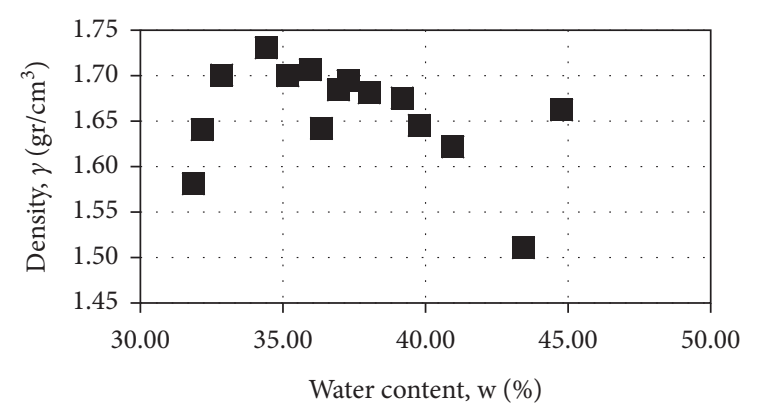

FIgURE 5: Decreased water addition.

decreased correspondingly with the increment of clay ratio. This result does not fit the requirements of soil that can be used as filter material, which allows less than $5 \%$ of clay contained in the material where the clay will be sticky (cohesive) and very soft [18]. However, the soil from the surrounding area may still be used as body dam material with proper compaction, as referred to in SNI 8062:2015 (Earth-fill Dam Regulation). The relationship between clay and sand ratio in soil with respect to the coefficient of permeability is shown in Figures 6 and 7.

\subsection{Relationship between Water Content and Permeability.} The value of the coefficient of permeability is also related to water content. The experiment was conducted with water content ranging between $32 \%$ and $49 \%$, which was insignificant indifference. The value of the permeability coefficient obtained was between $2.4 \times 10^{-4}$ and $1.4 \times 10^{-2}$, as seen in Figure 4. As a result, it is judicious to say that the sand/clay ratio affected the coefficient of permeability $(k)$ more than

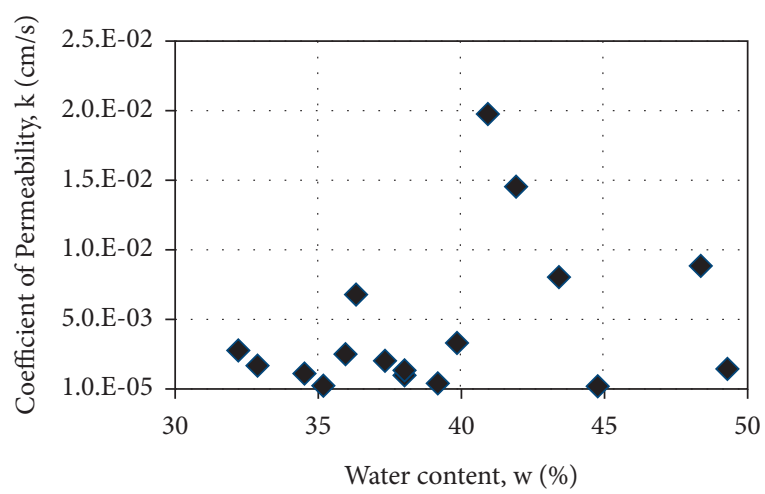

FIgURE 6: Relationship between clay/sand ratio and coefficient of permeability and water content.

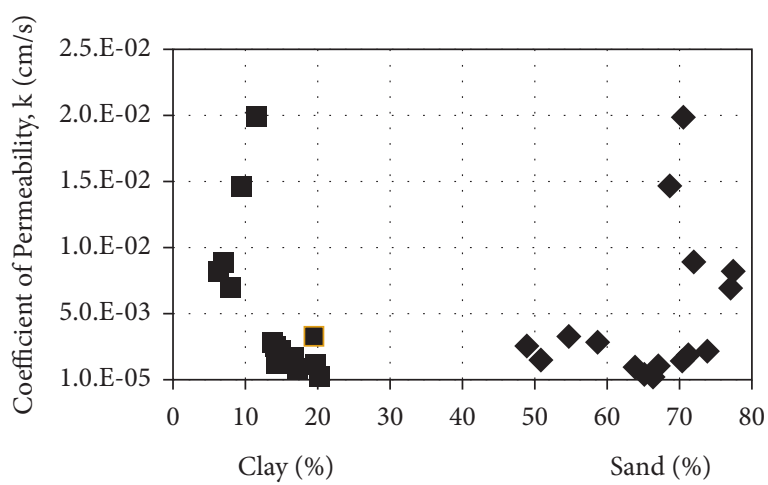

FIgURE 7: Relationship between the coefficient of permeability and water content.

the water content. This study also examined the dispersion degree of clay through visual examination, Emerson's crumb test, and pinhole test. The results of Emerson's crumb test showed that all samples could be categorized as Grade 1, which means that no colloidal cloud developed. Even though the crumb may slake and particles spread away from the original cloud because of this slaking activity, no trace of a colloidal cloud was observed in the chloride solution affecting the stability of the dam [9].

\section{Conclusions}

Based on the results of data analysis and processing, the soil stabilization for the dams using silt clay from Pringsewu and Margatiga subdistricts in East Lampung Regency, Indonesia, is as follows: An increase in the value of the friction angle is caused by an increase in water content up to $40 \%$. A decrease in cohesion is caused by an increase in water content and does not change much afterward. The optimum density value occurs when the water content is $32 \%$. The higher the moisture content, the lower the density. The highest cohesion value is obtained when water is added in its optimum volume which is between $37 \%$ and $40 \%$. Soil density values range from $1.15 \mathrm{~g} / \mathrm{m}^{3}$ to $1.35 \mathrm{~g} / \mathrm{m}^{3}$ in which the water content is between $35 \%$ and $40 \%$. The increasing addition of water reduces the compressibility value. The ratio of clay and sand affects the coefficient of permeability. The results show that 
the permeability coefficient decreases with increasing clay ratio. With testing on water content ranging between $32 \%$ and $49 \%$, the difference is not significant. Permeability coefficient values obtained are between $2.4 \times 10^{-4}$ and $1.4 \times$ $10^{-2}$. This proves that the sand/soil ratio affects the permeability coefficient $(k)$ more than the water content. Based on the laboratory tests of the soil, the results do not suit the needs of the soil, which can be used as a filter, which allows less than $5 \%$ of the clay contained in the material. However, soils from the area around the dam construction site taking place in Pringsewu and Margatiga subdistricts in East Lampung Regency can still be used as dam materials with proper compaction as referred to in SNI.

\section{Data Availability}

The data are available upon request from the authors.

\section{Conflicts of Interest}

The authors declare that they have no conflicts of interest.

\section{Acknowledgments}

This research was supported by the Institute for Research and Community Services of Universitas Lampung, Indonesia, through the research grant in 2020 .

\section{References}

[1] J. Albaladejo, E. Diaz- Pereira, and J. De Vente, "Eco- holistic soil conservation to support land degradation neutrality and sustainable development goals," Catena, vol. 196, Article ID 104823, 2020.

[2] N. A. Kocheeva, V. Roldugin, V. E. Katz, and T. I. Manankova, "Sulfate ion in the groundwater in the basin of mayma river (Northern Altai, Rusia," Periodico Tche Quimica, vol. 16, no. 33, pp. 315-324, 2019.

[3] D. Neina, "The role of soil $\mathrm{pH}$ in plant nutrition and soil remediation," Hindawi Advances Journal in Engineering, vol. 2019, pp. 1-9, 2019.

[4] S. I. Haruna and N. V. Nkongolo, "Variability of soil physical properties in a clay-loam soil and its implication on soil management practices," ISRN Soil Science, vol. 2013, pp. 1-8, 2013.

[5] D. Lei, L. Liu, and X. Zhu, "Prediction of soil water characteristic curve based on soil water evaporation," Hindawi Advances Journal in Engineering, vol. 2021, pp. 1-14, 2021.

[6] T. Cui, F. Tian, T. Yang, J. Wen, and M. Y. A. Khan, "Development of a comprehensive framework for assessing the impacts of climate change and dam construction on flow regimes," Journal of Hydrology, vol. 590, Article ID 125358, 2020.

[7] Y. Zhang, J. Liao, Z. Pei, X. Lu, S. Xu, and X. Wang, "Effect of dam construction on nutrient deposition from a small agricultural karst catchment," Ecological Indicators, vol. 107, Article ID 105548, 2019.

[8] S. Poudel, S. J. Abbey, and S. Ngambi, "Mechanism of hydraulic fracturing in cohesive zone of embankment dam cores - a review," International Journal of Civil Engineering \& Technology, vol. 8, no. 7, pp. 1202-1213, 2017.
[9] K. Behzad and F. Nazeri, "Effect of materials quality on stability of embankment dam," Electronic Journal of Geotechnical Engineering, vol. 21, pp. 5061-5071, 2016.

[10] H. Wu, J. Chen, J. Xu et al., "Effects of dam construction on biodiversity: a review," Journal of Cleaner Production, vol. 221, pp. 480-489, 2019.

[11] Secretariat Office - Dam Safety Commission (Dam Safety Center), Guidelines for General Dam Design Criteria, Department of Settlement and Regional Infrastructure, Directorate General of Water Resources, Jakarta, 2003.

[12] X. Jiang, D. Lu, E. Moran, M. F. Calvi, and L. V. Dutra, "Examining impacts of the Belo Monte hydroelectric dam construction on land-cover changes using multitemporal Landsat imagery," Applied Geography, vol. 97, pp. 35-47, 2018.

[13] A. A. Firoozi, C. Guney Olgun, A. A. Firoozi, and M. S. Baghini, "Fundamentals of soil stabilization," International Journal of Geo-Engineering, vol. 8, no. 1, p. 26, 2017.

[14] J. Bowles, Physical and Geotechnical Properties of Soil (Soil Mechanics), Erlangga, Jakarta, Indonesia, 2nd edition, 1984.

[15] H. C. Hardiyatmo, Soil Mechanics I, PT Gramedia Pustaka Umum, Jakarta, Indonesia, 1999.

[16] P. Verhoef, "Geology for civil engineering. Jakarta: erlangga. Figural and numerical strategies for generalizing patterns in algebra," Edited by J. L. C., M. S. Alatorre and A. Mendez, Eds., in Proceedings of the 28th annual meeting of the North American Chapter of the International Group for the Psychology of Mathematics Education, vol. 2, pp. 95-101, Universidad Pedagogica Nacional, Melbourne, Australia, 1994.

[17] K. U. Totsche, W. Amelung, M. H. Gerzabek et al., Microaggregates in soils, vol. 181, pp. 104-136, 2018.

[18] K. Terzaghi and R. B. Peck, Soil Mechanics in Engineering Practices, Erlangga, Jakarta, 1987.

[19] Z. Fu, H. Su, and Z. Wen, "Multi-scale numerical analysis for linear elastic behavior of clay concrete," International Journal of Solids and Structures, vol. 203, pp. 23-45, 2020.

[20] M. Charai, H. Sghiouri, A. Mezrhab, M. Karkri, and E. K. Hammouti, "Comparative study of a clay before and after fired brick-making process," Materials Today: Proceedings, vol. 31, pp. S103-S108, 2020.

[21] L. Wang, L. Tang, Z. Wang, H. Liu, and W. Zhang, "Discussion on probabilistic characterization of the soil-water retention curve and hydraulic conductivity and its application to slope reliability," Computers and Geotechnics, vol. 124, Article ID 103603, 2020.

[22] G. O. Ihekweme, J. N. Shondo, K. I. Orisekeh, G. M. KaluUka, I. C. Nwuzor, and A. P. Onwualu, "Characterization of certain Nigerian clay minerals for water purification and other industrial applications," Heliyon, vol. 6, no. 4, Article ID e03783, 2020.

[23] C. H. Khor and H. A. Shamsuddin, "Risk management for the moneying dam upgrading and enlargement project," in Proceedings of the International Conference on Dam Safety Management and Engineering (ICDSME), pp. 148-157, Penang, Malaysia, 2019.

[24] ASTM International, ASTM E2399/E2399M-15 Standards Test Method for Maximum media Density for Dead Load Analysis of Vegetative (green) Roof Systems, ASTM International, West Conshohocken, PA, USA, 2015.

[25] C. Wang, J. Liu, J. Feng, M. Wei, C. Wang, and Y. Jiang, "Effects of gas diffusion from fracture to coal matrix on the evolution of coal strains: experimental observations," International Journal of Coal Geology, vol. 162, pp. 74-84, 2016. 
[26] J. L. Sherard, L. Dunningan, R. S. Decker, and F. Steele, "Pinhole test for identifying dispersive soils," Journal of Geotech Engineering. Divison. ASCE, vol. 102, pp. 287-301, 1976.

[27] A. S. M. Hafizh, G. Wibisono, and A. S. Nugroho, "Stabilization of Clay Soil with various sand gradation and lime mixture," National Conference on Civil Engineering and Infrastructure - I, pp. G-45-G-55, Department of Civil Engineering, University of Jember, Regency, Indonesia, 2017. 